\title{
Vintage Lifestyle as Popular Culture on Indopinups Community in Indonesia
}

\section{Rahmadya Putra Nugraha}

\author{
Fakultas Ilmu Komunikasi Universitas Mercu Buana, Indonesia
}

\begin{abstract}
This study isentitled vintage lifestyle as popular culture on indopinups community in Indonesia. The purpose of this research is to find out the meaning of vintage lifestyle for members of the Indopinups community and to find out the communication behavior that is commonly practiced by the Indopinups community. This research used phenomenology method. The result of this study indicated that the Indopinups community vintage lifestyle was closely related to popular culture and also communication. Community members communicated withothersby using lifestyle attributes that became their characteristic that were part of popular culture. Communication behavior in this community is very unique and different from other groups, it has a special term. Beside of the terms commonly used in verbal communication, there were also many special terms for each genre and fashion, hair style and pin up makeup. Some of them also have special nicknames or more popular nicknames such as those often used by pin up icons and Hollywood celebrities
\end{abstract}

Keywords - Lifestyle, vintage, popular culture, community, Indonesia.

\section{INTRODUCTION}

Lifestyle is broadly defined as a way of life that is identified by how people spend their time (activity), what they consider important in their environment (interest), and what they think about themselves and also the world around them (opinion). According Sutisna (2008: 145) community's lifestyle will be different from other community, even from time to time the lifestyle of an individual and certain community group will move dynamically. However, lifestyle does not change rapidly, so at certain period of time the lifestyle is relatively permanent.

Lifestyle is someone's lifestyle in the world that expressed his or her activity, interest and opinion. According to Minor and Mowen (2002), lifestyle is a way to show how to spend money and how to allocate time. The lifestyle concept used in this study is the way a person displays his or her identity through the use of time, money and goods. To be able to achieve a lifestyle that is desired, usually a person must allocate more or extra costs. The expenditure of excess costs triggers someone to consume goods and services. So it can be concluded that lifestyle reflects the whole person who interacts in their environment. Therefore, it can be concluded that lifestyle is a lifestyle of someone expressed in their activity, interest and opinion in spending their money and how to allocate time.

The vintage lifestyle fan group is part of the new culture (counterculture). The vintage lifestyle fan group is part of the new culture (counterculture) as a phenomenon including in Indonesia. A set ofvalues in formoflocal wisdom from a culturethat has been passed down from generation to generation or often referred to as a highculture (adiluhung) beganto gain counterculture(Farid Hamid\& Nucifera, 2019:1013)

According to Kotler (2014: 309) lifestyle is a way of expression that is basic and unique that emerges in the field of human business. Meanwhile, according to Lamb, Hair and Mc Daniel (2008: 80) lifestyle is a way of life (fashion of living), is a way for people to decide how they will live their life. According to Sutisna (2008: 148) to measure lifestyle in term of cultural aspects, this program is referred as VALS 1 (Value And Life Stile 1) which consists of: 1) Outer directed, which is the lifestyle of consumers in purchasing product must in accordance with traditional values and norms that have been formed. Motivation of purchase is influenced by how the views and thoughts of other people. 2) Inner directed, a group of consumers who buy product to fulfill their inner desire to own something and not think too much about the developing cultural norms. 3) Need driven, is a group of consumers who buy something based on their needs and not the desires of the various choices are available.

Littlejohn gives the opinion of communication that we do every day will not be separated from the context of the group. The existence of group as a context of conversation in which individuals have a reference to group and to form group in showing their own boundaries and certain communication pattern in the community 
(group) either the present situation or prediction in the future (Stephen \& Foss, 2011:263).

Therefore, communication in group context is very important and still has overlap with interpersonal communication context. The most important focus in group communication can be observed in two dimensions, first; the existence of individual in forming and managing group through group contextual communication. Second, sorting out activities or maintaining continuity with the division of structure and task through communication carried out by the group itself.

Group communication in community context is an interesting discussion to study because each community group has its own characteristic and uniqueness that will not be found in other group. As is the case with the vintage lifestyle enthusiast group that was the target of this study. This group also has its own uniqueness that cannot be found in other groups, which is loved by the vintage lifestyle in millennial era.

This vintage culture that is now loved by Indonesian young people has actually existed since 1950 especially in America and England. Greaser is a subculture that developed in the United States around 1950. During that period, many young people loved Rock \& Roll music and then developed their creation into automotive art, mural, fashion, and even hairstyle. At first, Greaser was a form of counter culture as a part of the population of a society that strongly embraced one or more cultural values that were different from the values that existed in dominant culture.

The phenomenon of the outbreak of the Greaser can be found in various big cities in Indonesia. Their existence is sufficient to rely on social media. Greasers generally form community according to their interest. Currently in Indonesia there are more than 180 communities consisting of vintage automotive enthusiast community, the old music community, the graffiti community, the pomade fan community, and pin-up girls who were the female fashion icons of the era..

Pin up comes from the word pinned up which means to stick on the wall. During World War II, American soldiers had a habit of attaching photograph or poster of women both their wives or artists on the wall of plane and ship to encourage them during the war..

Pin up girl has actually been around since 1890. The explosion of Pin Up girl occurred when Esquire Magazine published Varga's Girls by Alberto Varga and the works of George Petty, both as front cover, calendar and match book. Even more exploded when Dior made an advertising campaign by using the concept of Pin Up Girl.
Then the Pin Up style exploded everywhere in America. This era began from the end of 1940 to 1960.

Indonesian Pin Up Community or better known as Indopinups is a community for women who love Pin Up Lifestyle. It is called Lifestyle because the concept is different from cosplay that is occasionally, in daily life the members of the Indopinups community always use the vintage characteristics of clothing, makeup and hairstyle in appearance. Since it was formed on 27 April 2015, the Indopinups community currently consists of around 150 people who come from various regions in Indonesia, especially big cities like Jakarta, Bogor, Bandung, Yogyakarta, Surabaya, Bali, and others. In this community, they share knowledge about fashion in vintage lifestyle.

This phenomenon becomes a very interesting discussion to study because this community has a unique communication behavior so it can maintain the existence of western culture in the past amid the influences of modern American popular culture and even Korea or Japan popular culture that is growing rapidly today. The purpose of this study is to find out the meaning of the vintage lifestyle for members of the Indopinups community and to know the communication behavior that is commonly practiced by the Indopinups community.

\section{LITERATURE REVIEW}

\section{Lifestyle as Communication}

Lifestyle can be understood as an individual's active adaptation to social condition in order to meet the need, to unite and socialize with others. Personality is considered as a determinant of lifestyle, and because each person's personality is unique, so lifestyle is unique.

Lifestyle is understood as a way of life that reflects the attitudes and value of someone. However, when a lifestyle spreads to many people and becomes a mode that is followed, understanding of lifestyle as a uniqueness is no longer sufficient to be used. Lifestyle is no longer merely a private or unique procedure or habit of the individual, but becomes an identity adopted by a group of people. A lifestyle can be the norm and is followed by many people. They do not hesitate to follow it if it is considered good by many people (Hendariningrum at all, 2008).

\section{Popular Culture and Lifestyle}

Popular culture or pop-culture is mass culture that is produced by mass and consumed by the mass. Popular culture is forms of social behavior and how mass items are used (Burton, 2012: 39). The birth of various forms of media also influences the development and spread of a 
culture in groups within society. A culture that has entered into the world of entertainment will place the popular element as its main element. This popular culture plays a major role in influencing a person's thinking in understanding other people or groups because pop culture is a culture that can be accepted by all people.

In social science, lifestyle is a way of how someone lives. According to Assael, lifestyle is how a person lives and spends his money after his or her primary needs are met, and how a person allocates his or her free time (Assael, 1988:57).

Pop culture is seen as the meaning and practice produced by the pop audience at the time of consumption and the study of pop culture is centered on how it is used. These arguments show that there is a struggle for traditional question about how the cultural industry turns people into commodities that serve their interests. (Baker, 2016)

In the pattern of social life, lifestyle problem cannot be separated from cultural terminology. As stated by Kephart, ordinary culture is defined as "The overall lifestyle of a society is more or less as their habits / customs, attitudes and values as society. But this definition, according to Chaney, is an abuse of the idea about lifestyle. While lifestyle depends on cultural forms, each is a style, manner, how to use certain goods, place and time that are characteristic of a group, but not their entire social experience (Ibrahim, 2011:307).

In the flow of popular culture, lifestyle plays an important role in building the existence of humans who live in the culture. Lifestyle is considered as a reflection of the identity of a person or group of people. Lifestyle in the flow of contemporary culture then raises two things that are the same but at the same time different, namely alternative and differentiation. Alternative means more resistance to the flow of mainstream cultural (Sari, 2011).

\section{Group Communication}

A group is a group of people who have a common goal that interacts with each other to achieve a common goal, get to know each other, and view them as part of the group.

Komunikasikelompokadalahkomunikasi yang berlangsungantarabeberapa orang Group communication is communication that takes place between several people in a "small" group such as in meeting, gathering, and conference and so on. Michael Burgoon defines group communication as face-to-face interaction between three or more people, with known goals, such as sharing information, protecting themselves, solving problem, where members can remember the personal characteristics of other members appropriately. (Wiryanto, 2005)

Therefore in this study, group communication is focused in form of interpersonal interaction that occurs in terms of discussion, production of work and gathering together in widening knowledge in the community.

\section{Alfred Schutz's Phenomenology}

Phenomenology research tries to explain or uncover the meaning of concept or phenomena of experience based on consciousness that occurs in some individuals. Phenomenology is carried out in natural situation, so there are no limits in interpreting or understanding the phenomenon being studied and the researcher is free to analyze the data obtained (Kuswarno, 2009:2).

Alfred Schutz explains how phenomenology can be applied to develop knowledge into the social world. Schutz focused on the way people understand the consciousness of others, but he lives in the flow of selfawareness. The perspective used by Schutz to understand consciousness is the inter-subjective concept. What is meant by this inter-subjective world is life-world or the world of daily life (George \& Goodman, 2007:94).

Intersubjectivity is a real-world provision and does not require fundamental explication that we see the world that forms community. The social sciences concretely confront with the real social reality that has been manipulated by transcendental phenomenology. Schutz's thought is a critique of a number of earlier phenomenology that view reality as a transcendental space that can only be viewed by certain circles. Everyday experiences of humans are formed through category or typification that separate from everything and are also driven by social awareness.

\section{George Herbert Mead's Symbolic Interaction Theory}

The theory of symbolic interaction was first coined by George Herbet Mead (1863-1931). However, Herbert Blummeris Mead's student who confirmed the theory of symbolic interaction as a study of various subjective aspects of humans in social life.

Symbolic interaction theory is based on ideas about people and their relationship with society. People are moved to act based on the meaning they give to people, things, and events. These meanings are created in language, which people use both to communicate with others and with themselves or their personal thoughts. Language allows people to develop feelings about themselves and to interact with other people in a community (West \& Turner, 2009:98).

Thus, symbolic interaction assumes that humans can understand things by learning from experience. A 
person's perception is always translated in symbols. A meaning is learned through interaction between people, the meaning arises because of the exchange of symbols in social group.

\section{METHODOLOGY}

In this study, the researcher used qualitative research approach. Qualitative approach is better understood as data development. When data developed, it will make it possible to see key aspects of a case more clearly (Neuman, 2006: 72). Then the method of this research was Alfred Schutz's phenomenology, which focused on intersubjectivity. Schutz views that the understanding of action, speech, and interaction is a prerequisite for any social existence (Cresswell, 1998: 53). Phenomenology can be interpreted as a study of the phenomena or things that appear. In broad meaning, phenomenology means the knowledge of symptoms or anything that appears. In narrow meaning, the knowledge of symptoms manifests themselves in our consciousness.

Phenomenology used was the Alfred Schultz's phenomenology that argues to understand consciousness with the concept of intersubjectivity. What is meant by this intersubjective world is life-world or the world of daily life (Kuswarno, 2009: 1-2). In choosing the subject of the study, the researcher used purposive method, where the subject of the elements included in the informant is done intentionally, with the note that the informant is based on certain characteristics that are considered to have relevance to the characteristics of the subject that were previously known (Ruslan, 2010:157).

In determining research subject, the researcher determined the following criteria: 1) The subject is the member of the Indopinups community in the city of Jakarta, 2) The subject is the member of group that actively contribute or influence the development of the Indopinups community, 3) The subject is the member of the Indopinups community who has joined more than one year.

From the criteria above, the appropriate research subjects were as follows: 1) Ms. DechaMuchtar - Founder of Indopinups Community, 2) Ms. Jeanette Jacobus Indopinups Community Committee, 3) Ms. SyarahUlyaIndopinups Community Committee, 4) Ms. Brenda Laurentia Dago- Member of Indopinups Community, 5) Ms. TriskaSarwono - Member of Indopinups Community. The selection of Indopinups community as the research subject was because this community has a very strong role in the development of vintage lifestyle which is usually dominated by men. Pin Up Girl has become an icon of the classical era.
To ensure the validity of data, the researcher implemented triangulation technique, which is to compare and check the degree of confidence in the information obtained by: (1) comparing observational data with interview data (2) comparing the consistency of the respondent's answers, namely by comparing what the respondent said in public with what the respondent said in private (3) comparing the perspective of someone with others in his or her work team (Kusuma, 2018:53).

\section{RESEARCH FINDING}

Based on the result of the research that has been done by researcher in the Indopinups community, there is a correlation between the pin up lifestyle, popular culture and communication as expressed by Kotler in Setriyaningsih 2012, lifestyle is the lifestyle of a person in the world expressed in the activities of interest and opinion. Lifestyle describes the "whole person" in interacting with their environment. Lifestyle also shows how people live, how to spend their money, and how to allocate time in their lives. Lifestyle can also be seen from their daily activity and what interest is needed in their lives.

Meanwhile, according to Kephart (1982) lifestyle is the pattern of actionthat distinguishes between one person and another. Lifestyle is a culture, which has the overall definition of a community's lifestyle, habit / custom, attitude, value, and the same understanding that unites them as a society (Syahrela,2006:47).

Popular culture or pop-culture is mass culture that is produced by mass and consumed by mass. Popular culture is forms of social behavior and how mass items are used. The birth of various forms of media also influences the development and spread of a culture in groups within society. Vintage and pin up culture has entered the world of entertainment through a variety of art performances both music and performance art that will place the popular element as the main element that can be seen from a number of world figures who became the pin up icon. This popular culture plays a major role in influencing someone's way of thinking in understanding other people or groups because pop culture is a culture that can be accepted by all people.

The Indopinups community communicates through the pin up lifestyle attributes inherent in them that express their expression and interest, both in appearance and in their thought and perception. The lifestyle they live is a form of popular culture that developed and people in pin up era brought and disseminated by the influence of the mass media that developed at that time until now.

\section{Communication behavior}


The types of communication used in the Indopinups community were group communication and intrapersonal communication,this is indicated by the existence of communication interaction carried out in their group that is more focused on the core group in the community and promote interpersonal communication to interact with fellow members of the community. Communication is based on symbolic interaction theory with the perception equality and using symbols in group communication. Symbolic interaction theory is the relationship between symbol and interaction. According to Mead, people act based on symbolic meaning that arise in a particular situation. Symbol is a representation of a phenomenon, where the previous symbol has been mutually agreed in a group and is used to achieve a common meaning together.

The result of the research on Indopinups community showed that there was description of the meaning constructed from the communication behavior of the members in this community through the way they used special symbols in their appearance in interacting and communicating in their group. For instance, the use of special term in communicating both in conversation or verbal communication such as katz, kitten, or vixen and how the waythey named clothe and hairstyle as well as special calls or pseudonyms on some members of the community and also pin up icon that become their idol.

Erving Goffman in his book entitled "The Presentation of Self in Everyday Life" states that social life consists primarily of ritual theatrical performance. The point is that we as humans act as actors who are playing a play on the stage where the social environment around them has a role as an audience that either directly or indirectly sees the performance. Everything that is done and attached to him or her that is exhibited in front of everyone. Then there arose various interpretations of what was worn by someone or consumed. Interpretation of what the actors used was produced views on the class or economic strata. It can be a factor why people compete to do consumerism and show it to the public (Goffman, 1959:40).

\section{Motive for Communicating}

From the result of observation and research on the Indopinups community, there were three motives for the reason and goal of the members of the community to join. If described, there was one common motive as the reason for them to join the community which was the similarity of hobby about culture in pin up era, it could be clothing, makeup, film, or music. The motive that became their goal to join the Indopinups community included the desire to add and share information about where to get vintage item, how to care, how to mix and match fashion style and also how to apply makeup and hair. There was also a motive for developing a business such as Brenda and Syarah who produced vintage clothing and accessories.

The explanation above is in accordance with the theory of phenomenology of Alfred Schultz in which Schutz mentions the concept of the motif which is divided into two, namely in order to motive is a motive that is used as a foothold by someone to do something that aims to achieve result, while because motive is a motive that looks backward.

\section{The Meaning of Vintage Lifestyle}

Phenomenology describes the meaning of a life experience for some people about a concept or phenomenon. People involved in dealing with a phenomenon explore the awareness structure of human life experiences. Kuswarno said that Phenomenology seeks to understand how humans construct important meaning and concept within the framework of intersubjectivity (our understanding of the world is shaped by our relationship with other people) (Kuswarno, 2009:2).

The result of the research showed the experiences and awareness of community members who from their childhood were already accustomed to vintage culture such as listening to music, watching movie, and wearing vintage clothes belonged to their parents or grandmothers, until they were already joined in other vintage communities for example lowrider bikes.

Their experience and awareness constructed the meaning of vintage lifestyle, especially pin up and also the meaning of community for them. Pin up is not cosplay but a lifestyle that they do every day, not only clothing and makeup but also thought. In millennial era, pin up is not reborn because in truth pin up never dies. The Indopinups community means something to them like finding a sister in passion and also a place where they share knowledge about the lifestyle they live. In life the members of the Indopinups community also held conservative values that developed during the pin up period including women must be strong and able to do many things but still look beautiful and carry out their nature, women must be open minded and be able to accept differences and not be judgmental.

\section{CONCLUSION}

From the result of research conducted on the Indopinups community, it can be concluded that the vintage lifestyle that they live was closely related to popular culture and also communication. Community members were communicated by using lifestyle attributes that became their characteristic and were part of popular culture. Communication behavior in this community was 
very unique and different from other groups, it has a special term. Beside of the term commonly used in verbal communication, there were also many special terms for each genre, fashion, hair style and pin up makeup. Some of them also have special nicknames or more popular nicknames such as those often used by pin up icons and Hollywood celebrities. Despite many bad stereotypes and unpleasant responses from the public, members of the Indopinups community continued to respond the negative responses by educating the public, by publicizing their existence and also by sticking to the meaning of vintage lifestyle as the product of culture.

\section{REFERENCES}

[1] Assael, H. 1998. Consumer Behavior and Marketing Action 6th edition. NewYork : International Thomson Publishing.

[2] Baker, Chris. 2016. Cultural Studies, Theory and Practice, diterjemahkan: Nurhadi, Cultural Studies, Teori\&Praktik. Bantul: KreasiWacana

[3] Burton, Graeme. 2012. Media danBudayaPopuler. Yogyakarta: Jalasutra

[4] Creswell, J. W. 1998. Qualitatif Inquiry and Research Design. Sage Publications, Inc: California

[5] George Ritzer dan Douglas J. Goodman, 2007. TeoriSosiologi Modern, terjemahanAlimandan. Jakarta: Kencana

[6] Goffman, Erving 1959.Presentation of Self in Everyday Life. New York: Doubleday Anchor Books.

[7] Hamid Farid \& Nucifera ZulvianaOriza. The Vintage Lifestyle as a Group Identity (Study in Alfred Schutz Phenomenology on Indonesian Pinups Community). International Journal of English, Literature and Social Science (IJELS). Vol-4, Issue-4, Jul - Aug 2019

[8] Hendariningrum, Retno\& M. EdySusilo. 2008. Fashion Dan Gaya Hidup: Identitas Dan Komunikasi. Jurnal Ilmu Komunikasi Volume 6 No 2

[9] Ibrahim, Idy Subandi. 2011. Budayapopuler Sebagai Komunikasi. Yogyakarta: Jalasutra

[10] John C. Mowen, Michael Minor. 2002, PerilakuKonsumen (Jilid 1), EdisiKelima, Jakarta: Erlangga

[11] Kotler, Philip. \& Gary Armstrong. 2014. Principle Of Marketing, 15th edition. New Jersey: Pearson Prentice Hall.

[12] Kusuma Kurniastuti. Activities of the Cyber Public Relations of O Chanel TV in Promoting their Company on the Instagram Social Media. American Journal of Humanities and Social Sciences Research (AJHSSR) Volume-02, Issue-09, pp-50-56. 2018.

[13] Kuswarno, Engkus. 2009. Metodologi Penelitian Komunikasi Fenomenologi. Bandung: WidyaPadjadjaran

[14] Littlejohn W. Stephen dan Karen A. Foss. 2011. TeoriKomunikasi. Jakarta: SalembaHumanika

[15] McDaniel, Lamb Hair (2008). Eseential of Marketing, USA: International Thompson Publishing
[16] Neuman LW. 2006.Social Research Methods Qualitative and Quantitative Approachs. Boston: Pearson

[17] Ruslan, Rosady. 2010. Metodepenelitian Public Relations danKomunikasi. Jakarta: PT. Raja Grafindo Persada.

[18] Sari, WulanZati. 2011. Budaya Pop dan Gaya Hidup (studikasuskorea lovers di Makassar). Skripsi Universitas Hasanuddin Fakultas Ilmu Sosial dan Ilmu Politik Makassar.

[19] Sutisna, 2008, Perilaku Konsumendan Komunikasi Pemasaran, Bandung: Rosdakarya

[20] Syahrela, Riza. 2006. Representasi Gaya Hidupdalam Iklan Televisi (Analisis Wacana: Iklan Kosmetik di Televisi). TesisUniversitas Indonesia FakultasIlmu Sosialdan Ilmu Politik Jakarta.

[21] West Richard, Turner Lynn H. 2009 Teori Komunikasi, Jakarta: Salemba Humanika

[22] Wiryanto. (2004). PengantarIlmuKomunikasi, Jakarta, Grasindo. 